\title{
Learning Pyramid Models To Improve Early Childhood Science Skills
}

\author{
Masitowati Gatot \\ Lecturer of Education Faculty, Ibn Khaldun Bogor University \\ Jl. KH.Sholeh Iskandar KM 2, Kota Bogor, Indonesia
}

\begin{abstract}
This study was to produce a valid and effective models to improve science process skills. Validity of learning gained through expert validity and limited testing (one to one and small group). Learning effectiveness is measured through a simple experiment using 9 (nine) step model of Borg, Gall and Gall. The aims of this methodology of research is to find how a teacher can implement teacher's guidance book study model pyramide based method. The result shows during pre test: $56,3 \%$ teachers teach in accordance with given criteria while $48,3 \%$ they don't. On the contrary, based on post test data: $93,3 \%$ teachers teach in line with the criteria, while $6,25 \%$ they don't. Meanwhile, the results of Students study in overall show there is an increase when students are conducting pre test and post test. The conclusions of this study are that the guidebooks produced and used, show improvement of teacher performance and improvement of basic science skills of children.
\end{abstract}

Keywords-science skill, pyramid models, early childhood, learning science process.

\section{INTRODUCTION}

Scientific process skills are tools used by children to explore the world around them and construct the concept of science, so it is important for teachers to be well-informed of these skills, as the skills of identifying and defining processes are not simple tasks.

Implementing learning science process skills can change the shape and direct the human personality in the form of improving the quality and quantity of a person. The importance of learning can change the performance (performance) of the before and after that are affected by the stimulus situation and the contents of memory.

Scientific process skills are also a combination of process and content skills where the child acquires new information through his experience with concrete objects. The learning outcomes of the science process skill is a tangible form that can be seen and felt from learning activities in the form of changes in the behavior of knowledge or understanding, skills and attitudes. Learning outcomes are divided into three types: (a). Knowledge and understanding (cognitive); (b). Skills;(c). Attitudes (affective).

Teachers should understand the importance of this science process skill, as one of the efforts to improve high-level thinking in children, which is a provision for children both at school and beyond, especially for problem solving. Habitation of children to observe, comparation,classification, measure, communicate will make children familiar with the data obtained then the child will learn to analyze from the information that has been stored previously with new knowledge obtained.

Higher order thinking in a child is different from simply memorizing because by thinking high level, a child will create his own concept of an object through the stages of the science process skills. Children construct information through exploration of concrete objects, for example by 
giving concrete objects rambutan fruit then the child will observe the rambutan fruit and then construct through the use of five senses, when given rambutan fruit there is rambutan skin red, green, rambutan fruit hair there is a long and there is a short, so the child has a high-level thinking. This will be different, if the child only get information in the form of images about rambutan fruit. This means that high-level thinking can not occur only because of nature (nature), but must be a learning (nurture).

The purpose of science process skills is to improve high-level thinking skills, this is supported by the relationship between the implementation of science process skills with language skills, math skills. In addition, the skills of the science process will also be useful for the child if it is outside the school environment, because this thinking ability that will make the child can interact with the surrounding environment, also children can learn to solve problems.

To overcome these problems required a method that can provide solutions for the learning process is done on an ongoing basis. The pyramid method can be the solution to this second problem. The pyramid method is a santifik-based method that has stages in the learning process, each stage must be done continuously. Stages in the pyramid method are orientation, demonstration, extension and deepening. These four stages must be done in order.

\section{Model Development Concept}

\section{LITERATURE REVIEW}

Models are often interpreted as conceptual frameworks used as guidelines for performing certain activities. The formulation of the model explicitly contains a number of interrelated elements, so that the required model [1]. Meanwhile, [2] the model is the result of the use of various systems approach in instructional design.

From the description above can be concluded that the model is a conceptual framework used as a guide in performing certain activities that contain a number of interrelated elements using various systems approach in instructional design. The existence of an instructional design in model development can guide us to know and understand the flow or flow of a model, from beginning to end.

The term model implies a representation of reality presented with a level of structure and order, and the model is usually ideal, simplified from realistic view [3]. [4] Harre (1960) in Richey identifies two types of models: micromorphs and paramorhs. Micromorphs are physical visual replicas, such as computer simulations or scale models of an object whereas paramorphs are symbolic models, usually using verbal descriptions. Harre notes, a simple example of paramorph is a verbal analogy. The more common paramorphs can be categorized as: conceptual models, procedural models, mathematical models.

Harre notes, a simple example of paramorph is a verbal analogy. The more common paramorphs can be categorized as: conceptual models, procedural models, mathematical models. From the expert's explanation of the above model, it can be concluded about the model and also the conceptual understanding of the model for this study, which is a series of logical, relating one concept to another, having a picture of reality or a simple representation of complex forms, serves to help understand something that is not experienced directly, either in physical or symbolic form.

Model development is one form of research from Research and Development (Research and Development), where it is necessary to differentiate from other objects or other phenomena. This is supported by the data presented in the form of summary (type diagram), configuration 
(structure), correlation (pattern), idealization, or a combination of the four data above. Thus, the model is a solid allusion, useful for comparing the relationship between the selected data and the chosen element of a logical construct.

The model is any organized stimulus, so the observer can draw the core information conveyed by events in that environment without doing it first.[5]

The model is a representation of some phenomena in the real world (a model is an abstract of reality, a simplified representation of some real world phenomenon). So the model is any organized stimulus, which is a representation of some of the existing phenomena [6].

Instructional Design is a systematic and reflective process, translating the principles of instruction and instruction into planning for material instruction, activities, information resources and evaluation [7]. This is supported by Dick, Carey and Carey [8] who stated that the instructional design is an umbrella of ISD (instruction system development) or instruction development system.

Instructional development is the same as instruktional design that is a systematic process in identifying problems, developing strategies and instructional materials, and evaluating their effectiveness and efficiency in achieving instructional goals [9]

Instructional design is a systematic and reflective process, translating the principles of instruction and instruction into planning for material instruction, activities, information sources and evaluation identifying problems.

According to Borg \& Gall, research and development is a process that is widely used in education and learning. The research and development procedure basically consists of two main objectives: (1) developing the product and, (2) testing the effectiveness of the product to achieve the goal. The first objective is referred to as a development function, while the second objective is referred to as a validation function.

The system according to Dick, Carey and Carey is a series of techniques whose parts are interconnected whereby all work towards a predetermined goal. Parts of the system depend on one another for input and output, and the whole system uses feedback to determine the goals to be achieved.

\section{Definition of Instructional Development Model}

Model development activities are more commonly used in the field of curriculum and learning because of the growing studies on curriculum development models and learning models.

The learning model is a set of components of an integrated learning strategy, including the phasing component and the sequence of material content ideas; use of overviews and summaries; use of examples; use of practice, and the use of strategy is also evaluation [10]

\section{Instructional Design Model}

The instructional design model is a teaching method designed to make learning more effective and interesting.

From the late 1980s to early 1990s, instructional design was developed on the basis of constructivism theory and other similar learning theories. This field development has driven a 
change in how technology is used in the classroom, as well as changes in how to use material taught to students.

Most instructional design models are based on the ADDIE framework, where there are five phases: analysis, design, development, implementation and evaluation. This phase is always followed in a model that is based on ADDIE's dynamic and flexible framework and allows the development of effective types of training and learning models.

Instructional design model, divided into three, namely: (1). System-oriented models, eg Dick \& Carey (Dick \& Carey Carey), Smith \& Ragan, Gentry, Diamond, Dorsey et.al., (Smith \& Ragan Model); al., (Kemp Model); (2). Class-oriented models, eg Gerlach Elly, Heinich et. al., (Assure Model) and Morison \& Kemp, et.al .; (3). Product-oriented model, eg Addie Model, Bergman \& Moore Model[11].

\section{Model Concept Developed}

The next discussion about the theoretical concepts underlying the model Development of basic science-based process learning skills pyramid method.

\section{Learning and Learning}

Learning is a process of behavioral change that exists in the individual, both with regard to aspects of logic, ethics, aesthetics, works and pratikta. Learning is a process of guided activities to achieve goals in order to change behavior.

The learning cycle is described as the process by which children move from the initial awareness of something to acquiring new knowledge and new skills that they can apply in various situations for themselves. Movements to acquire new knowledge may take several days, months or years depending on circumstances. The learning cycle consists of five phases namely awareness, exploration, acquisition, training, generalizing [12]

According to Thorndike in Gradler [13\}, in

learning process there are three laws that accompany, namely: (1). The law of effect which states that a satisfactory state after the response will strengthen the connection between appropriate stimulation and behavior, and the irritating state will weaken the connection; (2). The law of exercise which states that the repetition or repetition of experience will increase the probability of a correct response; (3). The law of readiness, which describes the conditions governing the so-called "satisfying" or "annoying" state [13].

The learning process depends on the experience the child has. The more experience the child has, the easier it will be for the teacher to determine the meaningful learning objectives for the child and then to give them the necessary experience for that purpose [14].

Of the three statements above can be concluded that learning and learning is very important for young children. The child's experience should be the foundation for teachers to set learning goals. This is so that children can follow the learning well and meaningful, because children already have a basis of learning. The learning process for early childhood should also be fun and must use concrete objects because early childhood can not think abstractly also stimulated by stimulating the five senses. 


\section{Social Learning Theory}

The social cognitive theory according to Bandura in Schunk is based on the attachment of mutual relationships between people, behavior and the environment in the learning process. The learning process will occur through direct practice or observation as well as role models.

Social teaching is a learning process that studies social behavior and emphasizes social interaction to achieve academic learning. The main role of educators is to prepare and develop democratic behavior in individual and social levels so as to achieve a productive social life.

This social teaching process argues that joint efforts can produce a happy quality of life and prevent any adverse social conflict. This learning process not only improves the social aspect but also produces the intellectual aspect, so the learning process to create a productive social behavioral development is based on the achievement of knowledge and academic skills.

The conditions created are a productive small society condition, not just a group of individuals who study each individually [15]. Given the role of the elder is the social role demanded of a father and mother, then in the learning model developed in communication between parent and child, how to stimulate the interaction between parent and child.

Bandura with his social cognitive theory asserts that the learning process is largely determined through the process of observation and modeling. Especially for early childhood, who can not think abstractly, then the two processes mentioned above that is observation and modeling is important, the child will imitate what he has seen.

In the learning process the learner must have attention, so as to be able to pay attention from what he observed, done retention or repetition of what he has observed in order to remember what has been given. The retention process is influenced by the verbal ability of the individual. Furthermore, the learners will keep the modeling process, the facilitator must help the participants to be able to produce what they learn, through behavior, in order to change their behavior can be done again, it takes an award or motivation from the outside to give encouragement for learners to make changes in their behavior repeatedly. Methods that can be used to create this observational learning process with demonstrations, films, television shows, display of a real event [16].

Behavioral Psychology Model is used to simplify instruction that will convey knowledge to students. The concept is more on the repetition and reinforcement of learners' behavior and knowledge. The instructions are to repeat until the correct answer or the desired response is received from the learner. The instructional design model based on the behavioral psychology theory struggles to teach the repetition of facts, definitions or concepts and associations. One example of the behavioral psychology model is the Dick and Carey system approach model. So it can be deduced that in the Dick and Carey model, repetition and reinforcement are performed, until the learner gets the results according to what has been the goal of the instructional design. This model considers the interests of the learner and as an active participant in the instruction.

One's success in learning is influenced by the environment and self efficacy. Essentially human learning from the environment through the process of interaction, behavior, examples and models (Schunk, 2012). Information that can be based on observation, listening to other people's experiences, and the experience of doing it on their own will create new beliefs and perspectives for each individual. It is these things that can shape knowledge, skills, and performance improvements, as a result of the planned learning process. 
In the model of cognitive psychology, learning is not just something that happens with exposure alone, but there is a change in brain structure of the learner and this requires the formation of new cognitive connections. This model deals with how the learner remembers the information, the focus is sometimes on creating a learning environment, which can help learners to connect new knowledge with previously known or experiences to participate. Learning occurs only when the learner can connect with new information to something that has been stored in his brain, and can call if needed. Teachers use accountable models to help make connections but the outcomes of the learner ultimately depend on how the learner acquires the information. This type of model is called a modern instructional design model, for example Reigeluth's elaboration theory, Bloom's learning taxonomy, Gagne's nine instructions, John Keller's ARCS model.

The constructivist model is one of the instructional design models, also known as the postmodern model, based on the concept that learners learn through experience and interaction. The theory behind this model suggests that what is best for learners is to do realistic, authentic tasks. It is intended that all knowledge is a personal interpretation of the information presented, and that the student is more important to the learning process of the teacher.

The use of this intruksional design model is used to help students with the delivery of learning beyond the delivery of teacher knowledge to students. More direct learning in the classroom, and instruction centered around activities as well as problems that are conveyed and resolved by the students, hence this method supports high learning skills and reflection thinking.

So as the implementation of this theory in communication education between parents and children, will use methods that involve participants to more actively interact through practice, simulation, reflection from the experience of communicating with children at home.

\section{Cognitive Learning}

Problem solving is one of the most important types of cognitive processing in the learning process. According to the learner, problem solving is a complex process, which must be able to solve and find solutions in achieving goals (Schunk, h 299, 2012). This method is done in accordance with the learning goals that have maturity in thinking. This problem solving is used in the communication model, because it is appropriate for parents who have maturity in thinking, and are required to assume certain responsibilities, as well as for children in order to learn to solve problems with simple materials according to age.

Gagne also describes some conditions that will affect the process of achieving the intellectual skills that occur in the learning process (Gagne and Briggs, 1979). Associated with a cognitive perspective in information processing, then the principle of learning is how to change the information received senses into stored memory passwords, for future use. So it is very important in the process of learning how to organize information to be learned, existing knowledge and process of understanding, understanding and storage and retrieval of stored information. Facts have shown that learners only respond to learning that can be understood actively. It is necessary to learn methods that can explore the perceptions of learners. The link between learning and the important tasks and knowledge they have. This activity can be done during pre-learning, as a preliminary step to bridge the attention of learners, using strategic teaching. Teaching that helps construct the meaning of prior knowledge, with the material being studied. How to create a summary and self-question. Summarizing aims to help capture the subject of learning, to distinguish important and unimportant ideas, and to synthesize key ideas. The process will enrich the understanding of the material to be studied. While the self- 
question is a metacognition strategy to check the extent to which the understanding and mastery of the material of learners (Gredler, 2011)

\section{Constructivism Learning}

The constructivism learning process is directed to build new knowledge and change old beliefs, by learning from the thinking power and experience of the participants. It is a focused way of learning to maximize learners' understanding. The learning process emphasizes the active role of learners in understanding the meaning and information learned from the context of their environment.

The learning process will occur when learners are actively involved in collaborative learning situations, through inquiring, explaining the phenomenon of existing issues and problemsolving processes encountered. The learning activities are fun and challenging, providing concrete tasks, connecting new knowledge that has been previously owned, so participants can reflect on what they learn. Constructivism learning process is very good for learning in the community that can not be separated from the social context. Learning methods used to facilitate it are by active learning, group learning and learning with practice. Because in essence learners will learn through the active involvement, through learning while working, where the participants will build or be able to create new knowledge with the knowledge they have, even the participants will think how to implement their new knowledge (Cruckshank, Deborah Brainer Jenkins, and Kim K. Metcalf, 2006)

\section{The concept of Early Childhood}

Early childhood is a group of people aged 0-8 years. It is at this time that the formation of character and personality is determined, through the naturally and experimentally nurturing. Early childhood is a different group of children in the process of growth and development, because it is unique that has a pattern of growth and development of cognitive, psychomotor, affective, and different languages

The golden age is the most important period for the formation of children's knowledge and behavior. At this time the ability of the child's brain to absorb information is very high. According to Gordon Dryden's records, the researchers prove that $50 \%$ of the child's ability is determined in the first 4 years, and 30\% before reaching eight years.

\section{Research purpose}

\section{METHODOLOGY}

The purpose of this study was to produce a Pyramide based learning model to improve the science process skills. This research applies research and development method which done by designing and developing teacher manual.

Reseacrh conducted in Indonesia. School sampling in this research is done by purposive sampling technique.

\section{Approach and Research Methods}

The approach used in this research is qualitative and quantitative approach.

This research is a development research known as R \& D (Research and Development), which is a development in the engineering process of a series of elements that are arranged together, to form a product 
Development is also an engineering process, which combines a number of elements together into a single product, thus forming a unified whole. Research development has three main components, namely development model, development procedure, and product trial.

The conceptual model is an analytical model, describes the relationships among several components, analyzes the details of several components to produce a product of development. The scope of development research involves a large area, encompassing various activities and interests, thus forming a study of the specific processes and impacts of efforts to design and develop. It is a comprehensive process, composed of various components that are an interrelated process. The process of blindly developing and conducting research, solving problems, producing products and tools in research in the form of products and tools in research in the form of learning or program. Stages that pass is the stage of analysis, design, development, and evaluation (Richey and Klein, 2007).

If the produced product is acceptable its feasibility then it can be continued with innovation dissemination process. If not already received, it is repeated for revision and repair. This study will only be carried out until the product trial stage by performing a formative evaluation. Formative evaluation results conducted by participating experts, and facilitators are implemented, using a one to one process, small group and field trials in the actual group. Formative evaluation results are inputs to revise the products that have been made, as well as an input at each stage that has been passed in research development.

The approach used is a mixed method research that is an approach that combines qualitative and quantitative research, because in this study required data that is qualitative and quantitative. The purpose of the merger is to strengthen the understanding of the phenomena that occur intact (Gay, Mills, and Airasian, 2009). Chreswell (2008) asserts that the design of the study using mixed methods aims to understand the problem of research, resulting in the process of integration and integration or linking. This is done when research requires deeper data and requires measurement, so using only quantitative or qualitative data alone can not find enough accurate information.

\section{The Steps of Development Models.}

Referring to the model design that has been discussed in theoretical studies, the steps to be systematically divided into three stages: preliminary research, model development planning, and validation, evaluation and revision. 


\section{The Steps of Development Model}
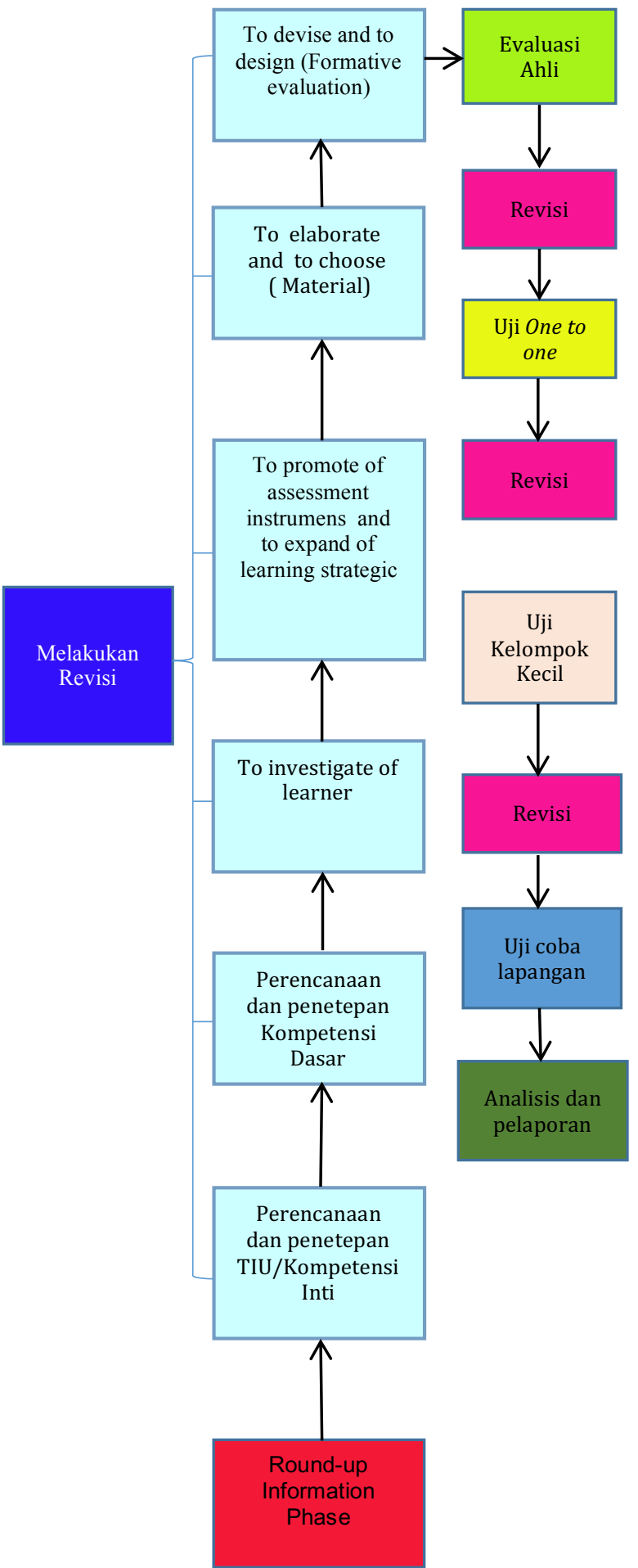


\section{RESULT}

The product of the Pyramid learning model to improve the science process skill is a teacher handbook.

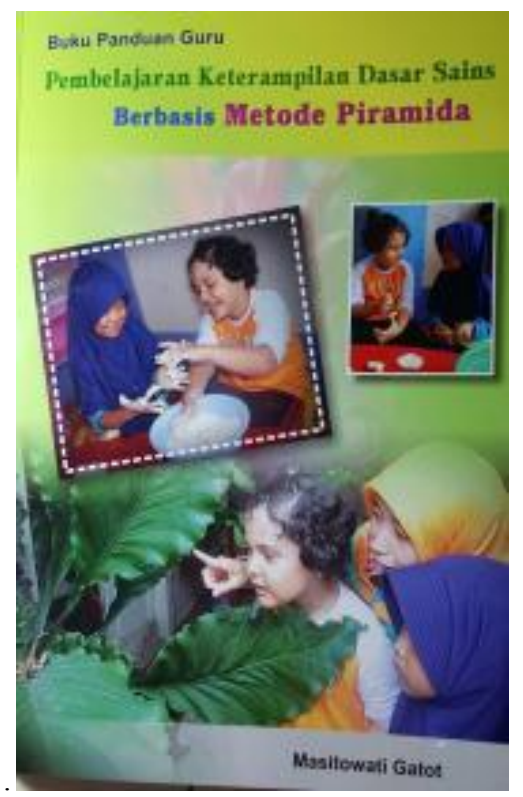

Figure 1. Teacher handbook

Research is done before the teacher using the handbook and after reading the handbook (pre test and post test).

Tabel 1. Instrumen for teacher

\begin{tabular}{|c|c|c|c|}
\hline No & Item & $\mathbf{Y}$ & $\mathbf{N}$ \\
\hline 1 & $\begin{array}{l}\text { Teacher gives words of affirmation that we can } \\
\text { all as long as we try to be as optimal as possible }\end{array}$ & & \\
\hline & $\begin{array}{l}\text { Teacher creates a pleasant classroom } \\
\text { atmosphere }\end{array}$ & & \\
\hline 3 & $\begin{array}{l}\text { Teachers build positive emotional relationships } \\
\text { with students }\end{array}$ & & \\
\hline 4 & The teacher provides early stepping activities & & \\
\hline 5 & Teacher explains the purpose of learning & & \\
\hline 6 & $\begin{array}{l}\text { The teacher explains what activities will be } \\
\text { carried out }\end{array}$ & & \\
\hline 7 & The teacher directs the child to observe & & \\
\hline 8 & he teacher directs the child to comparation & & \\
\hline 9 & The teacher to direct the child to classify & & \\
\hline 10 & The teacher directs the child to measure & & \\
\hline 11 & The teacher directs the child to communicate & & \\
\hline 12 & The teacher provides the core activities & & \\
\hline 13 & The teacher gives an explanation of action steps & & \\
\hline 14 & The teacher provides closing activities & & \\
\hline 15 & The teacher reviewed today's activities & & \\
\hline 16 & The teacher closes the activity with prayer & & \\
\hline
\end{tabular}




\section{Data Hasil Kinerja O2gä di RA BAKTI V,...}

Pre Test ${ }^{Y}$ Dost Test

Figure 1. Data Hasil Kinerja Guru di RA BAKTI V, Taman Cimanggu Bogor

From the data above is known that the performance of early childhood teachers before reading the manual (pre test) is equal to 56.25 percent of early childhood teachers follow the established criteria, while the remaining 43.75 percent have not run the criteria. When the post test teachers who have met the criteria increased to 93.75 percent, while 6.25 percent have not implemented the criteria set.

Learning development framework of the pyramid sciences process-based science process

Framework which is a combination of pyramid methods and science process skills

\begin{tabular}{|c|c|c|c|c|c|}
\hline \multirow{2}{*}{ metode piramida } & \multicolumn{5}{|c|}{ kps (keterampilan proses sains) } \\
\cline { 2 - 6 } & pengamatan & komparasi & klasifikasi & $\begin{array}{c}\text { cengukuran } \\
\text { (menghitung) }\end{array}$ & komunikasi \\
\hline orientasi & & & & & \\
\hline demonstrasi & & & & & \\
\hline Perluasan & & & & & \\
\hline Pendalaman & & & & & \\
\hline
\end{tabular}

Kisi-kisi Instrumen Keterampilan Proses Sains

\begin{tabular}{|l|l|l|l|}
\hline Variabel & Aspek & Indikator & Jml \\
\hline KPS & Kengamatan & Children can observe a variety of objects & 1 \\
\hline & Komparasi & $\begin{array}{l}\text { The child can compare various objects according } \\
\text { to size (large, small, short), shape or color } \\
\text { correctly } \\
\text { Children can create simple diagrams after } \\
\text { collecting data about various objects creatively }\end{array}$ & 3 \\
\hline & Klasifikasi & $\begin{array}{l}\text { Children can group a variety of objects by size, } \\
\text { shape or color correctly }\end{array}$ & 3 \\
\hline & Pengukuran & $\begin{array}{l}\text { The child can measure various ob-logs of length, } \\
\text { content, weight and time }\end{array}$ & 2 \\
\hline & Komunikasi & $\begin{array}{l}\text { The child is able to say words to expreate, } \\
\text { express, and convey thoughts, ideas, ideas and } \\
\text { feelings }\end{array}$ & 1 \\
\hline
\end{tabular}

Skills of the science process as variables will be assessed or scored based on the skill stage of the science process. 


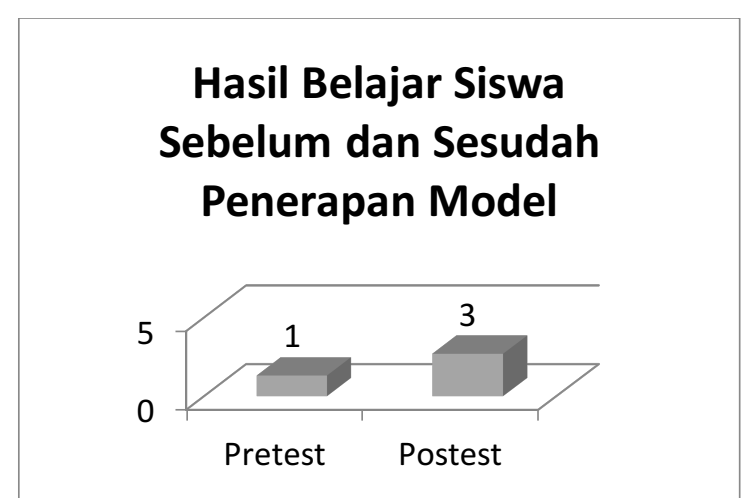

Figure 2. Hasil Belajar Siswa Sebelum dan Sesudah

From the above graph, the children's science process skills before the teacher applied the guidebook, the average assessment of PPP is 1 means that the child has not been able to implement the science process skills while after using the teacher manual, there is an increase of average PPP to 3, meaning that the child can perform the process skills science independently or without the help of teachers. This suggests that during the three-week meeting with the child in the learning process, the child can improve his skills, meaning that the teacher's manual is consistent with the characteristics of the child who wants an active and creative learning process with challenging activities, so that the child is happy to do so.

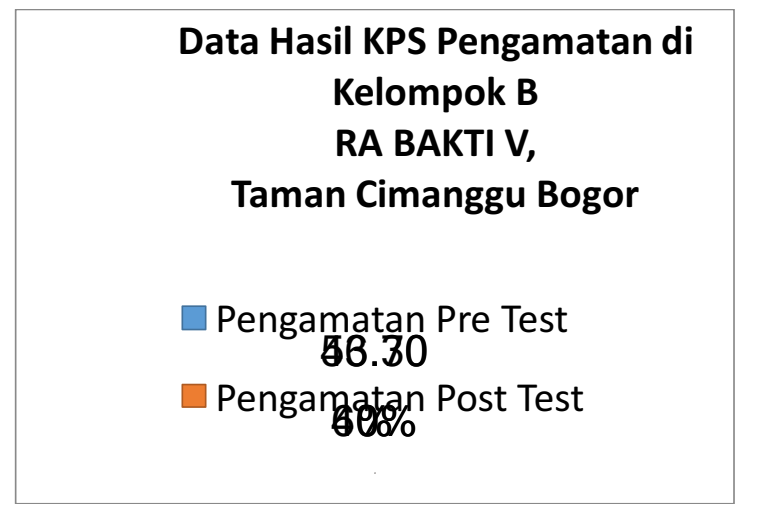

Figure 3. Graph of KPS Observation Results Group B in RA BAKTI V, Taman Cimanggu, Bogor

From observational science process skills it is known during pretest that 60 percent of children have not been able to make observations while 40 percent have been able to make observations with the help of teachers. After three weeks of learning process, post test result data showed that there was an increase because no children have not been able to carry out observation, the children who have been able to observe with the help of teachers is as much as 53.30 percent, while 46.70 percent of children can do observation without the teacher's help.

The possibility of this occurring is due to observation, when pre test of the child has not been stimulated to pass observation, after three weeks, the children showed a significant improvement with $46.7 \%$ increase of children have been able to observe without teacher assistance. It can be concluded that the process of habituation and stimulation using concrete objects can stimulate the child to be more skilled in observing 


\section{Data Hasil KPS Komparasi

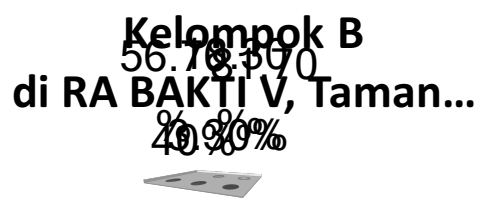

123

Pra Tes $\square$ Post Test

Figure 4. Results Data of KPS Group B Comparison in RA BAKTI V, Taman Cimanggu, Bogor

The results of pre-test for comparative study showed that 56.7 percent of children have not been able to make comparisons, 40 percent of children are still assisted by teachers to perform comparative activities, and 3.3 percent can make comparisons without the teacher's rock.

Data on post test results for comparison 81.7 percent of children can make comparisons without the help of teachers, while 18.3 percent are still assisted by teachers. This data indicates that the child has been able to compare better than before (pre test), possibly this is due to the repeated process of the learning process and it is evident that repetition in children aged 5-6 years is required.

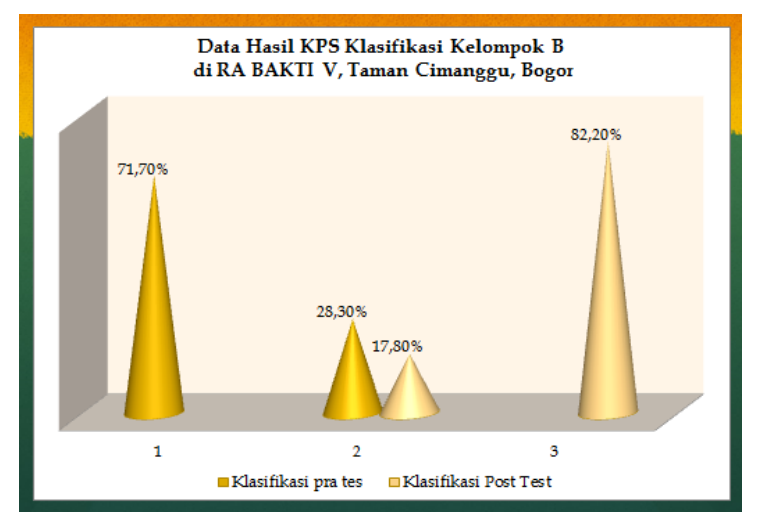

Figure 5. Results Data of PPP Class B Group in RA BAKTI V, Taman Cimanggu, Bogor

The data of pre test result for classification 71,7 percent of children have not been able to classify, while 28.8 percent of children have been able to do the classification although it must be assisted by the teacher.

Data of post test result for classification showed 82.2 percent of children can do the classification without the help of teachers while 17.8 percent are still assisted by teachers.

The data between comparison and classification indicates that the classification data is higher than comparison, it indicates that the child is more understanding about sorting than comparing though the percentage is not much different. 


\section{Data Hasil KPS Pengukuran \\ Kelompeg BA BAKTI V, \\ Taman Cimanggu, Bogor \\ 123}

Pra Tes $\square$ Post Test

Figure 6..Results of PPP Results Measurement Group B RA BAKTI V, Taman Cimanggu Bogor

The results of pre-test research for measurement showed that 53.30 percent of children have not been able to make measurements, while 46.7 percent of children can measure with the help of teachers.

Data from post test result showed that 16.7 percent of children were able to carry out measurements with the help of teachers while 83.3 percent of children can do measurements without the help of teachers.

\section{Data Hasil KPS Komunikasi Kelompok B di RA BAKTI V Taman Cimanggu Bogor 93.30

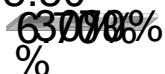 \\ 123}

Pre Test $\square$ Post Test

Figure 7. Data Result of KPS Communications Group B RA BAKTI V, Taman Cimanggu Bogor

Preliminary research data for communication showed that 93.3 percent of children have not been able to communicate, while 6.7 percent have been able to communicate with the help of teachers.

Data on post test results showed that 70 percent of children can communicate without the help of teachers while 30 percent of children communicate with the help of teachers.

Table 4:13 Data Results PPP Group B RA BAKTI V, Taman Cimanggu Bogor

\begin{tabular}{|l|r|r|r|r|r|r|}
\hline \multirow{2}{*}{ KPS } & \multicolumn{3}{|c|}{ Pre Test (\%) } & \multicolumn{3}{c|}{ Post Test (\%) } \\
\cline { 2 - 7 } & 1 & 2 & 3 & 1 & 2 & 3 \\
\hline Pengamatan & 60 & 40 & & & 53,30 & 46,70 \\
\hline Komparasi & 56,70 & 40 & 3,30 & & 18,30 & 81,70 \\
\hline Klasifikasi & 71,70 & 28,30 & & & & 83,30 \\
\hline Pengukuran & 53,30 & 46,70 & & & 16,70 & 32,20 \\
\hline Komunikasi & 93,30 & 6,70 & & & & 30 \\
\hline
\end{tabular}

The above data shows that overall there is an increase in the skills of the science process after the teacher provides this science process science learning through the guidebook. 
Of the five KPS that had the highest percentage of post test is the measurement (83.30\%) on the third scale and the lowest score is the observation (46.70\%) on the 3rd scale, it can be interpreted that the child who can perform the measurement without teacher assistance is $83.30 \%$ while the children who have been able to make observations without the help of teachers is $46.70 \%$. This increase is probably caused by a fun learning process for children is an active learning process using concrete objects so that children can explore an object using pancainderanya.

The use of senses is very important to obtain complete information through inquiry process so that children get information through the experience they do. Storage of information is very important given gradually so that will be arranged well, if at any time needed information then the brain will call it in the form of memory. The stored information is the result of gradual and systematic activities.

Pyramid method which in its implementation is done gradually ie orientation, demonstrasi, expansion and deepening will provide and store information from the activities undertaken. These stages will make the synapses in the brain work optimally.

\section{CONCLUSION}

Teacher guide model of pyramid-based learning model to improve science process skill can help improve teacher performance in implementing science process skill learning in children.

Based on data analysis of effectiveness test proved there is difference between pre test and post test at RA BAKTI V Taman Cimanggu Bogor.

If you want to improve the skills of the science process then use the pyramid-based learning model.

\section{References}

Jan Pouwer. "The Structural Configurational Approach a Methodological Outline" in The Unconscious in Culture. New York. Dutton \& Co. 1974. p243

M. Atwi Suparman. Modern Instructional Design. Publisher Erlangga. Jakarta. 2012. p 93.

Sugiyono. Qualitative Quantitative Research Methods and R \& D. 2014. Alfabeta Publisher. Bandung. h. 316.

Rita C. Richey, James D. Klein., And Monica W. Tracey. The Instructional Design Knowledge Base. Theory, Research, and Practice. 2011. Routledge Publ. New York. p8.

Margareth E. Gredler. Learning and Instruction .Pearson New York. 2011. 6ed. p546.

Stephen P. Robbins. Organizational Behavior: Concepts, Controversies, Application, 7 th Edition (Prentice Hall International, Inc. 1996), p.25

Rita C. Richey, James D. Klein, and Monica W. Tracey. op. cit., h.2

Walter Dick, Lou Carey, and James O. Carey. The Systematic Design of Instruction. 2009. Pearson Publ. USA. h.3.

M. Atwi Suparman. Modern Instructional Design. Guide of Educators and Educators. Ed fourth. 2014. Publishers publish. Jakarta. h. 104.

Charles M.Reigeluth. Instructional-Design Theories and Models: An Overview of Their Current Status (New Jersey. Lawrence Eribaum Associates, Inc. 1983). p.21

Gustafon and Branch. Survey of Instructional Development Models. New York: Clearing house of Information \& Technology, Syracuse University. 1997

Konstelnik, Soderman and Whiren. Developmentally Appropriate Curriculum. Best Practices in Early Childhood Education. Fourth Edition. 2007. Pearson Merrill Prentice Hall. h. 47-48

Margaret E. Gradler. Learning and Instruction. Teori dan Aplikasi. 2011. Edisi Keenam. Pearson. h. 56-57 
Paul Eggen dan Don Kauchak. Strategi dan Model Pembelajaran. Mengajarkan Konten dan Keterampilan Berpikir. Edisi Keenam. 2012. Indeks Penerbit. h.54

Bruce, Joyce, Marsha Well, dan Emily Callhoun. Models of Teaching (New Jersey Pearson Education. 2009). h. 295296

B.R. Hergenhahn dan Matthew H. Olson. Theories of Learning (Jakarta Kencana Prenada Media Grup, 2008). h. 383-385

Dale H. Schunk. Learning Theories An Educational Perspective Sixth Edition (Boston Pearson. 2012). hal. 119-120

B.R. Hergenhahn dan Matthew H. Olson. Theories of Learning (Jakarta Kencana Prenada Media Grup, 2008). h. 383-385

Dale H. Schunk. Learning Theories An Educational Perspective Sixth Edition (Boston Pearson. 2012). hal. 119-120

Dale H. Schunk. Learning Theories An Educational Perspective Sixth Edition (Boston Pearson. 2012). hal. 119-120

Dale H. Schunk. Learning Theories An Educational Perspective Sixth Edition (Boston Pearson. 2012). h.299

Robert M. Gagne dan Leslie J. Briggs. Principles of Instructional Design (Florida Holt., Rinehart and Winston, 1979). h 61-62

Margaret E. Gredler. Learning and Instruction. Teori dan Aplikasi (Jakarta. Kemcana Prenada Media Group. 2011). h. 248-255

Donald R. Cruckshank., Deborah Brainer Jenkins, dan Kim K. Metcalf. The Act of Teaching Fourth Edition (New York The McGraw Hill Companies. 2006). h. 254-256.

Rita. C. Richey dan James D. Klein. Design and Development Research Methods, Strategies and Issues (New Jersey: Lawrence Eribaum Associates, 2007), h 7-8

[1] Author 1, Author 2, "Title of paper", Name of Journal, Vol xx, No. x, pp. x-x, Year.

[2] Author(s), "Title of the proceedings paper", name of the conference, Publisher, Country, pp.x-X, Year

[3] Author(s), "Title of the Thesis", PhD thesis, ABC University, Year

[4] Author(s), this is a book title, publisher, Year

Title of Web Page, Webaddress, Last access/date of visit (dd-mm-yyyy) 